\title{
EFISIENSI PRODUKSI SAPI POTONG PADA PETERNAKAN RAKYAT PADA MUSIM KEMARAU DI DAERAH PERTANIAN LAHAN KERING KABUPATEN GUNUNGKIDUL
}

\author{
Eka Handayanta*, Lutojo dan Kurniasih Nurdiati \\ Program Studi Peternakan, Fakultas Pertanian, Universitas Sebelas Maret \\ *Corresponding author: ekahandayanta@staff.uns.ac.id
}

\begin{abstract}
This research was conducted to know the production efficiency of beef cattle in smallholder farmer in a dry farming area at dry season. Research has been started on June and finished on September (dry season) at smallholder farmer in the village Kemejing, Semin subdistrict, district Gunungkidul, DIY. The research materials are 28 heads of beef cattle from 17 farmers, which consist of 10 heads of PO breed, 10 heads of a Simpo breed, and 8 heads of Limpo breed with $292.25 \mathrm{~kg}$ of initial body weight. This research was using Participatory Rural Appraisal method which is a collecting data process that an active teamwork between data collector and farmer. Collected parameter are feed intake, average daily gain ( $A D G)$, feed efficiency, feed cost per gain $(F C / G)$, and income over feed cost (IOFC). Data resulting from this research are $8.42 \mathrm{~kg} / \mathrm{head} /$ day of feed intake, $0.19 \mathrm{~kg} / \mathrm{head} / \mathrm{day}$ of $A D G, 0.021$ of feed efficiency, $R p$ 46.166,62 of feed cost per gain, and $R p$ 3.985,55 of income over feed cost. It can be concluded that the efficient production of beef cattle in smallholder farmer at the dry area is low because average daily gain, feed cost per gain and income over feed cost produced are extremely small so if the calculated economic result is less favorable.
\end{abstract}

Keywords: Beef cattle; Feed intake; Feed efficiency; Income over feed cost

Cite this as: Handayanta, E., Lutojo, L., \& Nurdiati, K. 2017. Efisiensi Produksi Sapi Potong pada Peternakan Rakyat pada Musim Kemarau di Daerah Pertanian Lahan Kering Kabupaten Gunungkidul. Caraka Tani: Journal of Sustainable Agriculture. 32(1), 49-54. doi: http://dx.doi.org/10.20961/carakatani.v32i1.15928

\section{PENDAHULUAN}

Pertanian lahan kering adalah pertanian yang diusahakan tanpa penggenangan lahan garapan dimana sumber utama airnya bergantung pada curah hujan. Pertanian lahan umumnya mempunyai banyak permasalahan diantaranya lahannya marginal dengan ketersediaan air terbatas, terbatasnya varietas tanaman yang sesuai, belum berkembangnya teknologi budidaya, serta rendahnya pendapatan petani (Abdurrahman et al., 1997). Lebih lanjut dijelaskan bahwa produksi total hasil pertanian di daerah lahan kering, tidak dapat tinggi dan hasil produksinya tidak pernah lebih tinggi dari kebutuhan minimum untuk subsistensi, sehingga petani lahan kering tidak mungkin hidup layak jika ekonomi rumah tangganya hanya tergantung kepada hasil tanamannya.

Sistem usaha tani terintegrasi yang memadukan antara komoditas tanaman pangan dengan ternak menjadi suatu sistem pertanian terpadu (integrated farming system) diharapkan mampu memberikan keuntungan dan meningkatkan pendapatan petani, di lahan kering mengingat masing-masing komponen dapat saling bersinergi. Oleh karena itu untuk meningkatkan pendapatan, disamping bercocok tanam sebagai kegiatan utama, petani juga memelihara ternak.

Pengembangan usaha ternak sapi potong dapat dilakukan dengan memanfaatkan limbah pertanian (limbah tanaman pangan) seperti jerami padi, jerami jagung, jerami kacang tanah, daun ubi jalar, daun singkong serta limbah pertanian lainnya yang ketersediaannya sangat dipengaruhi oleh pola pertanian tanaman pangan di suatu wilayah.

Kebutuhan ternak terhadap pakan dicerminkan oleh kebutuhan terhadap nutriennya. Jumlah kebutuhan nutrien setiap harinya sangat tergantung pada jenis ternak, umur, fase (pertumbuhan, dewasa, bunting, menyusui), kondisi tubuh (normal, sakit) dan lingkungan 
tempat hidupnya (temperatur, kelembaban nisbi udara) serta bobot badannya (Parakkasi, 1995). Oleh karena itu setiap ekor ternak yang berbeda kondisinya membutuhkan jumlah pakan/ nutrien yang berbeda pula.

Faktor musim menjadi salah satu faktor penentu ketersediaan pakan khususnya hijauan pakan yang dapat menyebabkan terjadinya fluktuasi ketersediaan hijauan. Kuantitas, kualitas, dan kontinyuitas hijauan pakan tidak terjamin sepanjang tahun sehingga menyebabkan ternak tidak dapat berproduksi optimal. Produktifitas ternak ruminansia pada musim kemarau umumnya rendah karena mengkonsumsi pakan dalam jumlah dan kualitas rendah.

Permasalahan muncul ketika memanfaatkan lahan kering untuk usaha pertanian dan atau peternakan. Lahan kering yang umumnya miskin unsur hara, kurang air dan kurang subur, sehingga kurang produktif untuk menghasilkan sumber pangan dan bahan pakan. Performans sapi potong yang dipelihara masyarakat yang meliputi konsumsi pakan (BK), pertambahan bobot badan harian $(\mathrm{PBBH})$ rendah. Berdasarkan permasalahan tersebut di atas maka peneliti tertarik melakukan penelitian untuk mengetahui efisiensi produksi sapi potong pada peternakan rakyat pada musim kemarau di daerah pertanian lahan kering.

\section{METODE PENELITIAN}

\section{Tempat dan Waktu Penelitian}

Penelitian dilaksanakan selama 4 bulan pada musim kemarau, dimulai dari bulan Juni sampai dengan bulan September (musim kemarau berlangsung dari bulan April - September, sedangkan musim penghujan berlangsung dari bulan Oktober - Maret) di desa Kemejing, Kecamatan Semin, Kabupaten Gunungkidul.

\section{Bahan dan Alat Penelitian}

Sapi potong yang digunakan dalam penelitian ini milik 17 peternak responden berjumlah 28 ekor yang terdiri dari sapi Peranakan Ongole (PO) berjumlah 10 ekor, Simmental PO (Simpo) berjumlah 10 ekor, dan Limousin PO (Limpo) berjumlah 8 ekor dengan rerata bobot awal adalah $292,25 \mathrm{~kg}$.

Pakan yang diberikan pada sapi-sapi penelitian adalah sesuai dengan yang diberikan oleh peternaknya tanpa campur tangan dari peneliti, yang berupa rumput-rumputan (rumput kultur dan rumput alam), kacang-kacangan (legum), hijauan dari tanaman lain, dan limbah pertanian.

Peralatan kandang yang digunakan meliputi timbangan digital merk Great Scale tipe XK3190A7 kapasitas $2000 \mathrm{~kg}$ dengan kepekaan $1 \mathrm{~kg}$ untuk menimbang sapi, timbangan pegas merk Germany kapasitas $50 \mathrm{~kg}$ dengan kepekaan $0,5 \mathrm{~kg}$ untuk menimbang pakan, dan timbangan digital merk Camry kapasitas $50 \mathrm{~kg}$ dengan kepekaan $0,02 \mathrm{~kg}$ untuk menimbang sampel pakan.

\section{Pelaksanaan Penelitian}

Lokasi penelitian ditentukan secara purposive (sengaja) dengan pertimbangan waktu dan kemampuan serta jangkauan peneliti serta beberapa pertimbangan diantaranya adalah: (1) Desa Kemejing merupakan daerah dengan sistem pertaniannya lahan kering (100\%), dengan kepadatan ternak ruminansianya (UT/luas lahan pertanian) termasuk zone kepadatan tinggi di Kecamatan Semin, (2) Kecamatan Semin, kepadatan ternak ruminansianya (UT/luas lahan pertanian) termasuk zone kepadatan tinggi di Kabupaten Gunungkidul, dan (3) wilayah Kabupaten Gunungkidul merupakan daerah pertanian lahan kering $( \pm 90 \%$ sistem pertaniannya lahan kering) dan populasi ternak ruminansianya terutama sapi dan kambing tertinggi (rangking 1) di Propinsi DIY.

Penentuan peternak sapi potong sebagai sampel juga diperkuat alasan bahwa sapi potong menjadi salah satu komoditas unggulan dalam Renstra SKPD Dinas Peternakan Kabupaten Gunungkidul. Syarat ini diperlukan untuk memudahkan dalam menggali data informasi terkait dengan pengelolaan ternak sapinya.

Penentuan jumlah responden setelah syaratsyarat dalam pemilihan sampel peternak terpenuhi. Sebanyak 17 orang peternak ditentukan secara purposive sampling. Penentuan jumlah responden ini dengan pertimbangan akses lokasi (secara teknis dapat digunakan sebagai lokasi pengambilan sampel), waktu, tenaga, dan biaya sesuai dengan model penelitian yang bersifat partisipatif (Partisipatory Rural Appraisal). Syarat-syarat yang ditetapkan dari jumlah responden tersebut telah dapat memberikan gambaran yang mendekati kebenaran.

\section{Data Penelitian}

Penelitian dengan metode Partisipatory Rural Appraisal (PRA) yaitu proses pengumpulan data yang melibatkan kerjasama aktif antara 
pengumpul data dengan responden. Pertanyaanpertanyaan umumnya tidak dirancang secara baku, melainkan hanya garis-garis besarnya saja. Topik-topik pertanyaan bahkan dapat muncul dan berkembang berdasarkan proses tanya-jawab dengan responden (Singarimbun dan Effendi, 1995).

Metode dasar yang digunakan dalam penelitian ini adalah metode deskriptif. Penelitian deskriptif bertujuan untuk membuat gambaran mengenai situasi atau kejadian atau memberikan gambaran hubungan antar fenomena, menguji hipotesa, membuat prediksi serta implikasi dari suatu masalah yang ingin dipecahkan (Manti et al., 2003).

Data yang diperoleh dalam penelitian ini terdiri: konsumsi pakan (BK), pertambahan bobot badan harian $(\mathrm{PBBH})$, efisiensi pakan, feed cost per gain $(F C / G)$ dan Income Over Feed Cost $(\mathrm{IOFC})$.

\section{Analisis Data}

Data yang diperoleh dalam penelitian, bersifat kuantitatif dilaporkan secara deskriptif.

\section{HASIL DAN PEMBAHASAN}

Data performans sapi potong hasil penelitian yang meliputi konsumsi pakan (BK), pertambahan bobot badan harian $(\mathrm{PBBH})$, efisiensi pakan, feed cost per gain $(F C / G)$ dan income over feed cost (IOFC) seperti terlihat pada Tabel 1 berikut:

Tabel 1. Performan Sapi Potong Peternakan Rakyat Hasil Penelitian

\begin{tabular}{|c|c|c|c|}
\hline \multirow{2}{*}{ Parameter } & \multicolumn{3}{|c|}{ Nilai } \\
\hline & Terendah & Tertinggi & Rerata \\
\hline Rerata Konsumsi BK (kg) & 4,24 & 16,28 & 8,42 \\
\hline Rerata Kons BK trhdp BB (\%) & 1,91 & 5,19 & 2,74 \\
\hline Rerata PBBH (kg/ekor/hari) & $-0,07$ & 0,62 & 0,19 \\
\hline Efisiensi Pakan & $-0,02$ & 0,07 & 0,02 \\
\hline Rerata feed cost (Rp) & $4.225,40$ & $17.825,78$ & $7.831,31$ \\
\hline Feed cost per gain $(\mathrm{Rp} / \mathrm{kg})$ & $-77.241,14$ & $196.301,33$ & $46.166,62$ \\
\hline Income over feed cost $(\mathrm{Rp})$ & $-1.238,45$ & $13.248,08$ & $3.985,55$ \\
\hline
\end{tabular}

Sumber: data primer diolah

\section{Konsumsi Pakan}

Konsumsi pakan baik limbah pertanian dan hijauan rumput dihitung setiap hari dengan menimbang jumlah pakan yang diberikan serta menimbang sisa pakan jika ada keesokan harinya. Air minum diberikan pada ternak sapi potong ini adalah ad libitum dan dilakukan pergantian setiap hari.

Pada umumnya pemberian pakan dilakukan 3 kali sehari, yaitu pukul pagi, siang dan sore hari. Penimbangan pakan dilakukan oleh peneliti, untuk jumlah dan jenis pakan ternak sapi potong adalah sesuai yang diberikan oleh peternaknya tanpa campur tangan dari peneliti. Pakan ternak dicacah terlebih dulu untuk memudahkan dalam hal pemberian, lalu dimasukkan ke dalam karung dan ditimbang bobot pakannya serta dilakukan pencatatan dahulu sebelum diberikan pada ternak.

Berdasarkan data pada Tabel 1 di atas dapat diketahui bahwa rerata bahan kering yang dikonsumsi sapi tertinggi 16,28 terendah 4,24 atau rata-rata 8,42 masing-masing dalam kg/ekor/hari.
Rendahnya konsumsi pakan tersebut dikarenakan bobot badan awal sapi rendah sehingga kemampuan ternak mengkonsumsi bahan kering pakan sedikit. Perbedaan tingkat konsumsi BK karena variasi dari peternak dalam menberikan pakannya serta jenis dan bobot sapi yang dipelihara.

Pakan ternak yang dominan diberikan pada saat penelitian ini berupa limbah pertanian seperti jerami padi, jerami kacang tanah, jerami kedelai, dan jerami jagung. Beberapa peternak juga memberikan pakan berupa rumput-rumputan (gramineae) baik rumput alam/rumput lapang dan rumput kultur/rumput unggul (rumput Gajah), serta pakan ramban berupa daun pisang, daun mahoni, daun akasia dan daun nangka sebagai pakan ternak. Peternak tidak memberikan konsentrat untuk ternak sapinya karena harganya yang dirasa mahal.

Menurut Tillman et al. (1991), kemampuan mengkonsumsi pakan setiap sapi perharinya dalam bentuk bahan kering sebanyak 3\% dari 
bobot badannya. Rerata konsumsi bahan kering sapi yang diamati selama masa penelitian adalah $8,42 \mathrm{~kg} / \mathrm{ekor} / \mathrm{hari}$ atau sebesar $2,74 \%$ dari rerata bobot badan sapi potong, sehingga dari data tersebut dapat diketahui bahwa konsumsi bahan kering sapi selama penelitian hampir mencukupi dari kebutuhan.

\section{Pertambahan Bobot Badan Harian}

Penimbangan sapi potong dilakukan sebanyak tiga kali yaitu pada awal, pertengahan dan di akhir penelitian. Tujuan dilakukan penimbangan yang kedua adalah untuk kontrol apabila terjadi penjualan ternak sapi potong oleh peternak sewaktu-waktu.

Berdasarkan hasil penimbangan bobot badan sapi diperoleh rerata PBBH sebesar 0,19 $\mathrm{kg} / \mathrm{ekor} / \mathrm{hari}$. Nilai $\mathrm{PBBH}$ tersebut tergolong rendah jika dibandingkan dengan PBBH sapi PO jantan yang diberi pakan basal jerami padi dan dedak halus dengan aditif pakan kultur mikroba, didapatkan PBBH sebesar 0,38 kg (Bonga, 2003), sedangkan untuk rata-rata PBBH sapi SIMPO betina yang diberi pakan limbah hasil pertanian dan bekatul adalah 0,65 kg (Hasbullah, 2003).

Perbedaan PBBH dalam penelitian ini disebabkan oleh konsumsi bahan kering yang diberikan oleh peternak yang bervariasi jenis maupun jumlahnya pada tiap sapi, meskipun jumlah pemberian pakan banyak/tinggi akan tetapi nutrien yang terkandung dalam bahan pakan belum mencukupi kebutuhan ternak sehingga meskipun konsumsi BK tergolong normal tetapi PBBH yang dihasilkan rendah.

Menurut Parakkasi (1995), sapi yang memperoleh asupan nutrien kurang dari kebutuhan tidak dapat menunjukkan produktifitas optimal, karena untuk pertambahan bobot badan sapi harus terpenuhi kebutuhan bahan kering, protein kasar, dan energi.

\section{Efisiensi Pakan}

Berdasarkan data konsumsi BK dan pertambahan bobot badan harian maka dapat dihitung nilai efisiensi pakan dan feed cost. Efisiensi penggunaan pakan pada penelitian ini sebesar 0,021 yang artinya setiap $1 \mathrm{~kg}$ bahan kering ransum menghasilkan pertambahan bobot badan harian sebesar $0,021 \mathrm{~kg}$. Hasil yang didapat menunjukkan nilai efisiensi yang sangat rendah. Nilai efisiensi pakan yang rendah disebabkan karena rendahnya rerata PBBH yang disebabkan oleh rendahnya kandungan nutrien dari bahan pakan yang dikonsumsi sapi.

Nilai efisiensi penggunaan pakan yang semakin tinggi menunjukkan bahwa ransum yang dikonsumsi semakin sedikit untuk menghasilkan pertambahan bobot badan. Efisiensi penggunaan pakan dipengaruhi oleh beberapa faktor diantaranya kemampuan ternak dalam mencerna bahan pakan, kecukupan nutrien untuk hidup pokok, pertumbuhan dan fungsi tubuh serta jenis pakan yang digunakan (Sagala, 2011), umur ternak, kualitas pakan dan bobot badan. Semakin baik kualitas pakan semakin baik pula efisiensi pembentukan energi dan produksi (Pond et al., 2005).

Menurut Siregar (2001), efisiensi penggunaan pakan untuk sapi potong berkisar 7,52\% - 11,29\%, sedangkan rerata nilai efisiensi pada penelitian ini adalah sebesar $0,021(2,1)$. Hal ini disebabkan karena pakan yang diberikan oleh peternak pada saat penelitian berupa limbah hasil pertanian dan hijauan (rumput) yang mempunyai kualitas rendah dan tanpa diberikan legum ataupun konsentrat.

\section{Feed cost per gain}

Feed cost per gain $(f c / g)$ adalah besarnya biaya pakan yang diperlukan ternak untuk menghasilkan $1 \mathrm{~kg}$ gain (Suparman, 2004). Feed cost per gain ini dihitung berdasarkan pada harga pakan saat penelitian yang dikeluarkan setiap hari oleh peternak dibagi dengan rerata pertambahan bobot badan yang dihasilkan.

Hasil penelitian menunjukkan bahwa rerata nilai feed cost per gain $(f c / g)$ adalah Rp46.166,62. Ini berarti untuk menaikkan bobot badan sebanyak $1 \mathrm{~kg}$ diperlukan biaya pakan sebesar Rp46.166,62. Nilai $f c / g$ ini cukup tinggi, hal ini disebabkan oleh nilai efisiensi pakan yang rendah, sehingga walaupun sapi mengkonsumsi BK dalam jumlah yang mendekati standar tetapi tidak bisa memberikan PBBH yang baik. Pertambahan bobot badan harian yang dicapai tidak sebanding dengan biaya pakan yang sudah dikeluarkan.

Saat musim kemarau peternak sangat kesulitan mencari hijauan pakan di lahan pertaniannya sendiri, sehingga banyak peternak yang membeli pakan hijauan dari luar daerah dengan harga mahal yang mengakibatkan nilai feed cost tinggi. Angka feed cost per gain dapat ditekan dengan cara mengoptimalkan PBBH dan menekan biaya pakan dengan menggunakan pakan yang lebih efisien. Nilai PBBH dapat dioptimalkan dengan 
menerapkan manajemen pemeliharaan yang baik seperti pemberian pakan dalam jumlah yang cukup dan berkualitas, sanitasi dan kebersihan, dan tata laksana pemeliharaan kesehatan ternak (Williamson dan Payne, 1987).

\section{Income over feed cost}

Penghitungan Income Over Feed Cost (IOFC) dilakukan untuk mengetahui nilai ekonomis pakan terhadap pendapatan peternak sapi potong. Nilai income over feed cost tertera pada Tabel 2 berikut.

Tabel 2. Penghitungan Income Over Feed Cost

\begin{tabular}{llr}
\hline \multicolumn{1}{c}{ Income } & \multicolumn{1}{c}{ Perhitungan } & Nilai (Rp) \\
\hline PBBH & Rp22.000 x 0,19 & $4.180,00$ \\
Feses & Rp400 x 45\% x 15,4 & $2.772,00$ \\
Pedet & Rp3.000.000 x 6/148/28 & $4.343,63$ \\
\hline Total income & & $11.295,63$ \\
Feed cost & & $7.831,31$ \\
\hline Income over feed cost & & $3.464,32$ \\
\hline
\end{tabular}

Sumber: data primer diolah

Income over feed cost dihitung dengan cara mengalikan rerata PBBH dengan asumsi harga jual sapi per kg bobot hidup saat penelitian, yaitu Rp22.000,00. Income dari feses diperoleh dari penjualan pupuk yang berasal dari feses sapi yang ditampung oleh peternak. Kotoran ternak biasanya ditampung oleh peternak untuk kebutuhan pupuk di lahan pertaniannya sendiri, selebihnya akan dijual dalam bentuk kering tanpa proses pengomposan. Sapi Peranakan Ongole dewasa mampu menghasilkan kotoran sebesar 15 $\mathrm{kg} / \mathrm{ekor} / \mathrm{hari}$ (Deptan, 2001). Sapi yang dipelihara oleh peternak menghasilkan feses rata-rata sebesar 15,4 kg/ekor/hari dalam bentuk basah, sehingga income dari feses dihitung dengan cara mengalikan kisaran produksi feses harian sebesar $15,4 \mathrm{~kg}$ dengan kadar BK feses $45 \%$, kemudian dikalikan dengan asumsi harga feses kering per kg, yaitu Rp400,00.

Selama penelitian berlangsung, terjadi kelahiran pedet sebanyak 6 ekor, maka cara menghitung income dari pedet adalah 6 ekor dikalikan dengan asumsi harga pedet per ekor saat penelitian yaitu Rp3.000.000,00 kemudian dibagi dengan lama penelitian 148 hari dan jumlah ternak 28 ekor, sehingga didapat rata-rata income dari pedet untuk setiap ekor sapi yang diamati.

Berdasarkan perhitungan (Tabel 2), diperoleh nilai IOFC Rp3.464,32 yang berarti usaha peternakan sapi ini mendapatkan keuntungan sebesar Rp3.464,32 per ekor per hari. Nilai positif menunjukkan bahwa usaha yang dijalankan mengalami keuntungan walaupun kecil. Keuntungan yang kecil ini disebabkan oleh nilai income yang berasal dari PBBH sangat rendah.

\section{KESIMPULAN}

Kesimpulan yang dapat diambil dari penelitian ini adalah bahwa efisiensi produksi sapi potong pada usaha peternakan rakyat di daerah pertanian lahan kering adalah rendah. Konsumsi pakan (BK) terhadap BB sebesar 2,74\% dengan PBBH sebesar $0,19 \mathrm{~kg} / \mathrm{ekor} / \mathrm{hari}$, sehingga menghasilkan nilai efisiensi pakan sebesar 0,02 .

\section{DAFTAR PUSTAKA}

Abdurrahman, A., Ismail, I.G., \& Sutono. 1997. Dukungan Penelitian terhadap pertanian lahan kering. Dalam: Proc. Lokakarya Nasional Pertanian Lahan Kering Beberapa Kawasan Pengembangan Ekonomi Terpadu di Kawasan Timur Indonesia. Malang.

Bonga, S.M.D. 2003. PBB Sapi PO Jantan yang Diberi Pakan Basal Jerami Padi dan Dedak Halus dengan Aditif Pakan Kultur Mikroba (Skripsi S1). Yogyakarta: UGM.

Deptan. 2001. Teknologi Usaha Pengemukan Sapi Potong. BPTP. Jawa tengah.

Hasbullah, E.L. 2003. Kinerja Pertumbuhan dan Reproduksi Sapi Persilangan Simmental dengan Peranakan Ongole dan Sapi Peranakan Ongole di Kabupaten Bantul Daerah Istimewa Yogyakarta (Tesis S2). Yogyakarta: Universitas Gadjah Mada.

Manti. I., Azmi, E., Priyotomo, \& Sitompul, D. 2003. Kajian sosial ekonomi sistem integrasi sapi dengan kelapa sawit (SISKA). Prosiding Lokakarya Nasional Sistem Integrasi Kelapa - 
Sapi. Bengkulu, September 2003. Bogor: Pusat Penelitian dan Pengembangan Peternakan.

Parakkasi, A. 1995. Ilmu Nutrisi dan Makanan Ternak Ruminan. Jakarta: Universitas Indonesia Press.

Pond, W.G., Church, D.C., Pond, K.R., \& Schoknet, P.A. 2005. Basic Animal Nutrition and Feeding. 5th revised edition. New York: John Willey and Sons Inc.

Sagala, W. 2011. Analisis Biaya Pakan dan Performa Sapi Potong Lokal Pada Ransum Hijauan Tinggi yang Disuplementasi Ekstrak Lerak (Sapindus rarak) (Skripsi S1). Bogor: Institut Pertanian Bogor.

Siregar, S.B. 2001. Ransum Ternak Ruminansia. Jakarta: Penebar Swadaya.

Singarimbun, M., \& Effendi, S. 1995. Metode Penelitian Survey. Jakarta: LP3EI.

Suparman, D. 2004. Kinerja Produksi Kelinci Lokal Jantan dengan Pemberian Pakan Kering vs Basah (Skripsi S1). Yogyakarta: Universitas Gadjah Mada.

Tillman, A.D., Hartadi, H., Reksohadiprodjo, S., Prawirokusuma, S., \& Lebdosoekodjo, S. 1991. Ilmu Makanan Ternak Dasar. Yogyakarta: Gadjah Mada University Press.

Widiati, R. 2003. Analisis Linier Programming Usaha Ternak Sapi Potong dalam Sistem Rumah Tangga Tani Berdasarkan Tipologi Wilayah di Daerah Istimewa Yogyakarta (Disertasi S3). Yogyakarta: Program Pasca Sarjana UGM.

Williamson, G., \& Payne, J.A. 1987. An Intoduction to Animal Husbandry in The Tropics. Longman Group. London. Dalam Darmadja, D. (edt). 1993. Pengantar Peternakan di Daerah Tropis. Yogyakarta: Gadjah Mada University Press. 